\title{
"SE O ÍNDIO FOR ORIGINAL": A NEGAÇÃO DA COETANEIDADE COMO CONDIÇÃO PARA UMA INDIANIDADE AUTÊNTICA NA MÍDIA E NOS ESTUDOS DA LINGUAGEM NO BRASIL
}

\author{
"AS LONG AS THE INDIO IS ORIGINAL": THE DENIAL \\ OF COEVALNESS AS A CONDITION FOR AN AUTHENTIC \\ INDIGENEITY IN THE MEDIA AND IN LANGUAGE STUDIES
}

IN BRAZIL

\section{André Marques do Nascimento*}

\section{RESUMO}

Neste artigo, abordo a ideia de negação da coetaneidade e como ela toma forma em discursos da mídia e em pressupostos epistemológicos dos estudos da linguagem para os quais uma "identidade indígena autêntica" se faz importante. Para isso, inicio a discussão apresentando um caso radical e violento de materialização da negação da coetaneidade indígena na imprensa brasileira e busco, na sequência, aprofundar a compreensão desse conceito, desde seu contexto original de crítica interna à Antropologia, até sua apropriação e ampliação pelos estudos decoloniais. Desde esse aparato teórico, apresento instâncias de sua implementação em outros discursos jornalísticos hegemônicos no Brasil com os objetivos de demonstrar como essa negação é estratégica e atende a interesses supralocais que fazem com que circulem facilmente na sociedade. Finalmente, apresento a hipótese de que a negação da coetaneidade é implementada, talvez de forma mais sutil e naturalizada, em pressupostos teóricos dos estudos da linguagem que se dedicam às línguas e situações sociolinguísticas indígenas. Para isso, relato uma pesquisa empírica, de caráter metateórico, cujos resultados tendem a confirmar essa hipótese.

Palavras-chave: negação da coetaneidade; povos indígenas; identidade.

\section{ABSTRACT}

In this paper, I address the idea of denial of coevalness and how it takes shape in media discourses and in some epistemological assumptions of language studies to which an "authentic Indigenous identity" is presumably important. In order to do so, I begin the discussion by presenting a radical and violent case of denial of indigenous coevalness in Brazilian media, and I seek, in the sequence, to deepen the understanding of this concept, from its original context of internal criticism to Anthropology, passing through its appropriation by decolonial studies. From this theoretical apparatus, I present instances of its implementation in Brazilian hegemonic journalistic discourses aiming to make explicit

\footnotetext{
* Universidade Federal de Goiás (UFG), Goiânia (GO), Brasil. marquesandre@yahoo.com.br
} 
how the denial of coevalness is strategic and serves supralocal interests which make it easily circulate in society. Finally, I present the hypothesis that the denial of coevalness is implemented, perhaps in a more subtly and naturalized ways, in theoretical assumptions of language studies that focus on Indigenous languages and sociolinguistic situations. For this, I report an empirical research, of meta-theoretical approach, whose results tend to confirm that hypothesis.

Keywords: denial of coevalness; Indigenous people; identity.

\section{INTRODUÇÃO}

Em 23 de julho de 2018, quando, pela primeira vez na história do território que convencionou-se chamar Brasil, uma mulher indígena acabava de ser escolhida pelo seu partido para concorrer à vice-presidência da República e já circulava pelo território nacional apresentando suas propostas, o escritor, artista e produtor cultural makuxi, Jaider Esbell, publicou em seu perfil no Facebook uma postagem multimodal onde se lia, em seu "momento reflexivo", aqui entextualizado no Excerto 1:

\section{Excerto 1}

Toda vez que me dizem: - Eu queria conhecer a cultura indígena. Minha cabeça roda, roda, roda e eu fico tonto a ponto de cair no chão. Eu digo: - E agora, o que eu vou dizer para essa pessoa? É claro que eles querem saber da tribo, dos ritos, dos chás, das ervas, das curas e dos mistérios. Querem talvez ver o índio selvagem e puro. Digo sim, eles também existem, mas talvez não consigamos chegar lá a tempo. Eles querem ver só o lado bonito da história, os belos corpos pintados e a grande festa - felicidade. Não se consideram mais indígenas as pessoas com histórias atuais próprias.

O artista makuxi, assim como muitas outras pessoas indígenas na atualidade, muito provavelmente tem de lidar cotidianamente com o imaginário da sociedade não indígena brasileira que pressupõe e reproduz em seus discursos a "pureza" como índice de autenticidade de sua identidade étnica. A consequência mais grave deste imaginário é, como o próprio artista reconhece, que "não se consideram mais indígenas as pessoas com histórias atuais próprias".

A constatação de Jaider Esbell, potencializada por um posicionamento geo e corpo-político ${ }^{1}$ que o situa como um homem indígena num território colonizado,

1. Conforme elabora Mignolo, "a geopolítica do conhecimento define a localização histórica (espaço e tempo, os referentes históricos e a configuração do tempo e do espaço etc.) e a autoridade da localização das enunciações negadas e desvalorizadas" (MIGNOLO, 2010, p. 37-38) pela dominação colonial, ao passo que a corpo-política se torna um conceito complementar, por "tornar 
possivelmente é a materialização contemporânea mais radical de uma estratégia retórica que estruturou o mundo moderno/colonial, elaborada nos termos críticos do antropólogo Johannes Fabian como a negação da coetaneidade [denial of coevalness] que, em síntese, diz respeito a como "atribui-se às populações conquistadas um Tempo diferente" (FABIAN, 1983, destaques no original) ${ }^{2}$, sistematicamente, um tempo ligado ao passado.

Ao ser apropriada e ampliada por pensadores e pensadoras decoloniais, a ideia de negação da coetaneidade elaborada por Fabian ajuda a desvelar os mecanismos através dos quais as identidades étnico-raciais que se emergiram com o colonialismo foram subalternizadas precisamente por terem sido performaticamente instituídas como presas ao passado em relação ao conquistador europeu. Para justificar a violência colonial, foi preciso inventar o Outro como sendo o bárbaro, o primitivo, o selvagem e atrasado em relação à experiência moderna. Eram essas condições do Outro as próprias justificativas para a violência colonial implementada em forma de cristianização, civilização, desenvolvimento e progresso.

Apesar de tão antiga como a própria colonização, esta estratégia de negar que o Outro subjugado compartilhe o mesmo tempo daquele que o subjuga tem efeitos contemporâneos materiais reais nas vidas de indivíduos e povos indígenas, especialmente daqueles que, por razões distintas, desestabilizam em alguma dimensão a ideia de indígena preso ao passado ou, como descreve Esbell, "pessoas com histórias atuais próprias". Trata-se de uma estratégia usada contingencialmente para desqualificar vidas indígenas que, não correspondendo à identidade presa ao passado, deixam de ser indígenas e, a partir desta lógica, não têm legitimidade para demandar direitos culturalmente específicos, como o direito aos seus territórios, por exemplo. Estes discursos que negam a coexistência indígena num tempo presente compartilhado com as sociedades não indígenas, por se emanarem de e se vincularem às posições de poder, circulam socialmente com muita facilidade e explicitamente, como na imprensa hegemônica brasileira, mas, em outras vezes, de forma mais sutil e naturalizada, mas não menos grave, em forma de pressupostos teóricos de campos disciplinares que têm como objetos de estudo dimensões

visível a cor, o gênero e a sexualidade dos corpos pensantes" (MIGNOLO, 2010, p. 41) situados nessas localizações geo-históricas, como a América Latina, por exemplo. Como implementadas pelo pensamento decolonial, as concepções de geopolítica e corpo-política buscam afirmar e valorizar "o pensamento e a ação em regiões e corpos que foram desclassificados para pensar" (MIGNOLO, 2011, p. xxii). Trata-se, assim, de uma compreensão contra-hegemônica que põe em relevo o "sou onde faço e penso", numa atitude combativa à máxima cartesiana "sou porque penso", que desconsidera o onde por pressupô-lo no coração da Europa (MIGNOLO, 2011).

2. As traduções de citações usadas neste trabalho são de minha responsabilidade. 
específicas das experiências indígenas, como a Antropologia, alvo da crítica de Johannes Fabian.

Este preâmbulo iniciado com as palavras de um artista contemporâneo indígena tornadas públicas através de uma estrutura globalizada de comunicação, como o Facebook, ao mesmo tempo em que introduz as reflexões a serem apresentadas neste trabalho, mapeia a trajetória argumentativa que pretendo seguir. Assim, iniciando com um caso radical e violento de atualização da negação da coetaneidade de povos e indivíduos indígenas pela imprensa brasileira, busco, na sequência, aprofundar a compreensão desse conceito, desde seu contexto original de crítica interna à Antropologia, até sua apropriação e ampliação pelos estudos decoloniais. Desde esse aparato teórico, apresento instâncias de sua implementação em discursos jornalísticos hegemônicos no Brasil com os objetivos de demonstrar como a negação da coetaneidade é estratégica e atende a interesses supralocais e como circula facilmente na sociedade. Finalmente, apresento, e busco argumentar em seu favor, a hipótese de que a negação da coetaneidade é implementada em pressupostos teóricos dos estudos da linguagem que se dedicam às línguas e situações sociolinguísticas indígenas que, por negarem situações que caracterizam a contemporaneidade das experiências indígenas, acabam por reiterar e privilegiar uma identidade etnolinguística prefigurada (PINTO, 2013), ou seja, uma identidade que alegada e inequivocamente vincula, no caso de indígenas, etnicidade e práticas comunicativas, pressupondo uma relação direta entre língua, cultura e território. Para isso, relato uma pesquisa empírica, de caráter metateórico, cujos resultados tendem a confirmar essa hipótese.

Entretanto, não é meu objetivo neste texto discutir identidade per se ou o que configuraria uma "identidade indígena", por razões de escopo e espaço, mas, principalmente, por ter como objetivo destacar a negação da coetaneidade como uma importante dimensão da instituição performática, da representação, da negociação e mesmo da deslegitimação identitárias indígenas desde posições de poder. Neste sentido, não é sem propósito que alinho discursos da mídia hegemônica com discursos acadêmicos nesta reflexão, pois reconheço a ambos como discursos políticos e emanados de lugares privilegiados de enunciação e que, precisamente por isso, têm efeitos materiais reais na vida de quem, no geral, não compartilha desses posicionamentos geopolíticos, como são os povos e indivíduos indígenas no Brasil.

Da mesma forma, creio ser importante mencionar que minha compreensão de "identidade indígena" refuta perspectivas estáticas e radicais reificadas na ideia de tradições nativas imutáveis, se alinhando, ao contrário, com perspectivas que 
a concebem como construções histórica e socialmente situadas, contingenciais e relacionais, que surgem em campos sociais amplos de diferença e igualdade e adquirem seu significado positivo não de propriedades essenciais inerentes, mas em sua relação também com o que não a constitui, incluindo o que se considera "não indígena" (cf. BASTOS, LOPES, 2011; CADENAS, STARN, 2010; LOPES, BASTOS, 2010; MAHER, 2010; RAJAGOPALAN, 2003).

\section{1. "ALGUMA COISA CONTRA OS ÍNDIOS?... NÃO!": DESDE QUE SEJAM ÍNDIOS ORIGINAIS}

Em 25 de janeiro de 2017, enquanto atuava como docente na etapa de estudos do curso de Licenciatura em Educação Intercultural da Universidade Federal de Goiás, recebi uma mensagem de um de nossos estudantes indígenas pelo aplicativo de mensagens instantâneas Messenger, do Facebook, que suscitou uma breve e significativa conversa, entextualizada no Excerto $2^{3}$ :

\section{Excerto 2}

Estudante: Bom dia professor??

Estudante: Td bem?

Estudante: Hem professor eu queria conversar com vc sobre a reportagem da mulher da record

Estudante: Tem como??

Autor: Bom dia, R.

Autor: Tem sim, pode falar

Estudante: Se poderia como chamar a mulher que fez comentários sobre aos povos indígenas no seminário pra pedir desculpas e se explicar ou a gente entra contra com processo e contra TV record e ela tbm .. tem possibilidade??

Estudante: A gente podia conversar melhor sobre isso depois da aula .

Autor: Podemos conversar mais sobre isso, R.

Autor: No sábado estarei aí para o seminário

Estudante: Tá ok

Autor:

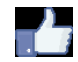

3. A publicação da conversa foi autorizada, por escrito, pelo estudante. Muito embora ele tenha sugerido que seu nome indígena fosse também divulgado, opto por seu anonimato. Para isso, utilizo o termo "estudante" para identificar seus turnos na troca de mensagens e "R." para abreviar seu nome, quando mencionado por mim, na interação. Além dessas substituições, a troca do meu nome de usuário no aplicativo por "autor" foram as únicas alterações textuais. 
Estudante: Porque isso estar doento muito, isso não pode ficar assim, porque falo isso onde estar as leis que fala sobre os direitos??

Autor: Eu te entendo R.! Foi uma ofensa muito grave. Vamos pensar sobre o assunto e quem sabe procurar alguém que entende mais, um advogado talvez. Eu vou buscar mais informações e aí a gente conversa

Estudante:

Estudante: Blza então isso q eu quero ver com vc

Estudante: Então a gente conversa no seminário blz

Autor: Combinado!

Retomando elementos daquele contexto, entendo que o estudante ter se dirigido a mim especificamente para manifestar sua tristeza e seu pedido se deva ao fato de eu ter trabalhado com outra turma de estudantes indígenas no mesmo curso, na semana anterior a essa conversa, o vídeo ao qual ele se refere. $\mathrm{O}$ trabalho pedagógico, que teve desdobramentos também nas redes sociais, certamente circulou entre muitos outros estudantes, como é o caso do autor da mensagem. A "reportagem" mencionada por ele foi veiculada em um vídeo de 5 minutos e 47 segundos, amplamente repercutido nas redes sociais àquela época. Nele, Fabélia Oliveira, apresentadora do programa Sucesso no Campo, transmitido pela afiliada da rede Record em Goiás, apresenta, de maneira bastante inequívoca e contundente, sua avaliação quanto à decisão de a escola de samba carioca Imperatriz Leopoldinense condenar, em seu samba-enredo de 2017, "Xingu, O Clamor que Vem da Floresta", a destruição que acomete as terras indígenas no Brasil e o Parque Indígena do Xingu, em particular ${ }^{4}$.

A reação do estudante, a propósito um indígena xinguano, é facilmente compreendida quando considerado o teor da fala da apresentadora, que aqui me parece bastante significativa por atualizar discursos sobre povos e indivíduos indígenas que se emergem na interseção de ideologias étnico-raciais, identitárias e linguísticas, cujos efeitos reais nas vidas indígenas têm sido extremamente nefastos. Dada a relevância de elementos que constituem o discurso da apresentadora para meus argumentos, transcrevo-o no Excerto $3^{5}$ :

\section{Excerto 3}

4. Vídeo disponível em https://www.youtube.com/watch?v=9aoNV5sMWp4. Acesso em: 15 set. 2018.

5. Convenções básicas de transcrição: ... pausas $_{i}$ : - prolongamento $:$ : - prolongamento mais acentuado; ? - entonação ascendente / - interrupção; " " - entextualização de trechos de outro discurso. 
móises santana aldir sena adriano ganso... o::u jorge do finge... você já ouviu falar esses nomes?... provavelmente não... e se ouviu foi agora recente... são autores compositores sambistas que têm toda uma história na cultura brasileira... mas também acabam de manchar a sua história... são eles... os autores... do::... polêmico já/especialmente dentro do setor do agro... samba enredo da escola leopoldo/ imperatriz leopoldinense... e aí a gente pergunta... quem são esses rapazes? que conhecimento o:: tradiciona:1 malandro carioca porque se eles não são cariocas mas ao menos eles têm bastante da cultura... urbana da cultura do samba da cultura carioca... que conhecimento que eles têm... pra falar... do homem do campo? pra falar do índio? pra falar da floresta? pra dizer que tá certo ou errado? pra dizer que alguém pede por socorro?... sabe que conhecimento que eles têm? o de uso da tecnologia... porque eles falam... que a floresta tá pedindo socorro... mas não abrem mão... da tecnologia do dia a dia... eles não abrem mão do veículo que eles andam... o agro está onde?... o agro está no dia a dia de todo mundo... todo mundo... "ah, mas o xingu tá pedindo socorro"... por que? alguém foi lá?/aí vem chamar... de heróis/inclusive eu tenho aqui ó... "andar onde ninguém andou... chegar onde ninguém chegou lembrar a coragem e o amor dos irmãos... e outros heróis guardiões... aventuras de fé e paixão o sonho de integrar uma nação"... os versos estariam perfeitos... para descrever o homem do campo o agricultor o pecuarista... não pra descrever índios... alguma coisa contra os índios? não... eles querem... preservar a sua cultura?... estão corretos e eu sou em favor disso... eles querem a mata pra preservar a cultura deles? pois então eles vão viver da cultura deles eu sou em favor dessa preservação se o índio for original... agora deixar a mata reservada... pra comer de geladeira isso não é cultura indígena não... eu sinto muito... a minha opinião pode chocar agora... muitos brasileiros... mas se o índio quer preservar a cultura ele não pode ter acesso... à tecnologia que nós temos/ ele não pode comer de geladeira tomar banho de chuveiro e tomar remédios químicos... porque há um controle populacional natural/ ele vai ter que morrer de malária de tétano... do parto... é... a natureza... se quer lá ele vai comer ele vai tratar na medicina que o cacique que o pajé ali que eles tinham... antigamente... aí justifica... agora e::u já passei em aldeias indígenas... onde tivemos que pagar o maior pedágio... que era cinco vezes superior ao tradicional e com estradas horríveis... e aí tá lá o índio... de raiban/num era falsificado não tá?... raiban espelhado aparelho nos dentes antena parabólica caminhonete railux... isso não é preservar isso não é heroísmo... heroísmo é o produtor que trabalha sol a sol... dia a dia... pra alimentar toda uma nação inclusive a indígena... que leva pra lá... o alimento porque não produz mais não tem mais aquela cultura... então... esses quatro rapazes... moisés santana... aldir sena... adriano ganso... e jorge da finge... eles estão muito equivocados... eles precisam sair de uma sala com ar condicionado... e ir... pro dia a dia do produtor rural... como agora aqui em goiás... que o produtor já não tá segurando a cabeça sobre o pescoço preocupado... com o veranico... como teve em montevidiu nesta 
semana chuva de granizo e que o seguro já teve que ser acionado... aí é heroísmo aí é ter fé é ter coragem... pra enterrar o... o seu investimento... e crer que ele é capaz... de fazer a diferença de fazer alguma coisa... nessa semana foi deflagrada uma campanha... e o sucesso no campo convida você... a participar desta campanha... é uma campanha pra arrecadação de recursos... pra colocarmos... painéis eletrônicos... pra colocarmos autidors... na avenida paulista... nos/na sapucaí no sambódromo em volta do/de tudo aquilo ali... e dizer quem é... o homem do campo... quem é o herói brasileiro que agora diante da pior recessão da história do país... ele foi capaz... de manter em ascensão... os empregos no país... manteve o pibi... a desgraça não tomou conta total do nosso país... por causa desse herói... do produtor rural... e é com toda essa indignação... que nós começamos o programa sucesso no campo de hoje... e esperamos... que a população urbana... passe a com/compreender e a conhecer esse produtor

Muitas dimensões do discurso da apresentadora poderiam ser aqui abordadas, pois parecem representar fidedignamente a visão de grande parte da população brasileira sobre povos e indivíduos indígenas ao longo de toda a história, como enfatizado pelo artista Jaider Esbell. Para minha análise interessada, faz sentido colocar em relevo, inicialmente, a própria violência discursiva infligida não só contra os autores do samba-enredo, mas, principalmente, contra os povos indígenas. A dor provocada no estudante indígena e a consequente demanda por um desagravo por parte da apresentadora são compreensíveis se, conforme Silva (2017, p. 03), entendemos que "a violência verbal é tão violenta quanto a violência física, não se tratando apenas de "meras palavras". Ao refletir sobre as dimensões da violência na/da linguagem, Silva chama a atenção para o fato de que diferentes formas de violência podem ser performadas através do discurso, quando o próprio sentido dos enunciados é violento, e que os efeitos nas vítimas são somáticos, uma vez que o "discurso injurioso e a violência verbal envolvem formas de desigualdade - insultos raciais prejudicam o corpo porque se fundam em desigualdades que foram geradas e mantidas antes mesmo da própria cena de injúria" (SILVA, 2017, p. 03).

A partir desta compreensão, creio ser possível reconhecer em muitos índices linguísticos acionados no discurso da apresentadora a condensação da longa historicidade da instituição de desigualdades, que remonta, ao mesmo tempo em que reitera e atualiza, a estratégia colonial de hierarquização racial do Outro não europeu e a consequente emergência de identidades subalternizadas, como "índios" e "negros", por exemplo (QUIJANO, 1992; 2000), sempre situados num passado em relação ao colonizador. Tais índices, aqui compreendidos como as formas linguísticas que "apontam para" aspectos de contextos sociais e culturais 
e se tornam "pistas interpretativas entre o que é dito e a ocasião social em que estão sendo produzidas" (BLOMMAERT, 2005, p. 11), podem ser identificados, por exemplo, em expressões como "se o indio for original", "que eles tinbam antigamente" e "não tem mais aduela cultura"

Ao se posicionar a favor do agronegócio, Fabélia utiliza argumentos no melhor estilo "eu estive lá" (discurso de autoridade tão antigo como o dos primeiros colonizadores!) para desqualificar os povos indígenas, também tomados, mais uma vez, de forma generalizante, com cultura no singular, e para julgá-los com base naquilo a que "não podem ter acesso" para serem indígenas. A historicidade das desigualdades e os efeitos reais e perversos que ela carrega e reproduz parecem não fazer parte da compreensão ou dos interesses da apresentadora. História e criticidade não enquadram ou constituem seu discurso. Para ela, pouco importam as trajetórias de violência outras que levaram, quase sempre de forma compulsória, as sociedades e os indivíduos indígenas às suas formas de vidas atuais. Apesar disso, ela se vê com autoridade suficiente para reconhecer uma indianidade "original" e, o mais relevante para minha argumentação, sempre vinculada ao passado. Ideia que busco aprofundar na próxima seção.

\section{NEGAÇÃO DA COETANEIDADE COMO GÊNESE DA VIOLÊNCIA MODERNO/ COLONIAL: A IMAGINAÇÃO DA "INDIANIDADE ORIGINAL"}

Para compreender criticamente esta imagem do indígena "original" como "o de antigamente" acionada por índices linguísticos no discurso de Fabélia, utilizo elementos da crítica à Antropologia Cultural formulada pelo antropólogo alemão Johannes Fabian. Em Time and the Other: how Antbropology makes its object (1983), Fabian faz uma crítica aos construtos teóricos da Antropologia, especialmente no que diz respeito aos usos contemporâneos e pretéritos do Tempo na construção deste campo do saber e de seu objeto, e destaca como essa construção, através de seus conceitos e aparatos temporais, é um ato político. Fabian é incisivo ao reconhecer como a etnografia e a etnologia tomaram forma como disciplina, assim como a própria prática antropológica, vinculadas ao colonialismo e ao imperialismo, contribuindo sobremaneira para a justificativa colonial. Neste sentido, argumenta o autor, a antropologia

promoveu um esquema nos termos dos quais não somente as culturas do passado, como todas as sociedades vivas, foram irremediavelmente colocadas em uma vertente temporal, um fluxo de Tempo - algumas fluindo para cima, outras para baixo. Civilização, evolução, desenvolvimento, aculturação, modernização (e suas primas, industrialização, urbanização) 
são, todos eles, termos cujo conteúdo conceitual deriva de formas que podem ser especificadas num Tempo evolucionário (FABIAN, 1983, p. 17).

Esta percepção evolucionária do tempo, aliada aos interesses colonialistas e tomada como fundamento epistemológico pela Antropologia, foi fundamental para a instituição do Outro (i.e. não europeu, colonizado) como pertencendo ao tempo passado, performaticamente construído num "discurso que emprega termos como primitivo, selvagem (mas também tribal, tradicional, de Terceiro Mundo ou qualquer outro eufemismo corrente)" (FABIAN, 1983, p. 18). A principal estratégia utilizada para a construção deste discurso é, através do uso do tempo, "distanciar aquele que é observado do Tempo do observador" (FABIAN, 1983, p. 25). O autor destaca, ainda, os riscos de contradição da pesquisa etnográfica que, para ocorrer, precisa de que pesquisador e pesquisado se envolvam pessoal e prolongadamente, que interajam e compartilhem um mesmo tempo, tempo esse chamado por ele de intersubjetivo; mas, por outro lado, como esta interação é apagada no discurso, geralmente escrito, que anuncia o conhecimento gerado pela pesquisa, quando o Outro é construído em termos de distância espacial e temporal. Neste sentido, assevera Fabian (1983, p. xi, acréscimo meu), "a presença empírica [do Outro] se transforma em sua ausência teórica".

Os aparatos de distanciamento identificados por Fabian produzem efeitos globais. Para se referir a esses efeitos, o autor formula a ideia de negação da coetaneidade e busca, através desta expressão, "indicar uma persistente e sistemática tendência em identificar o(s) referente(s) da Antropologia num Tempo outro diferente do tempo presente do produtor do discurso antropológico" (FABIAN, 1983, p. 31, destaque no original). Fabian, ao aprofundar sua análise dos mecanismos através dos quais a negação da coetaneidade se materializa na ciência antropológica, destaca o fato de que essa negação "se torna intensificada à medida que o distanciamento de tempo passa de um interesse explícito para um pressuposto teórico implícito" (FABIAN, 1983, p. 39), ou seja, se torna naturalizada e normalmente inquestionada como pressuposto teórico daquele campo de saber. Desde esta compreensão, Fabian reconhece como a negação da coetaneidade foi decisiva na hierarquização subalternizada do não europeu e na naturalização de uma representação idílica dos povos colonizados, especialmente de povos nativos/ indígenas, uma vez que, conforme o autor,

[a]lém da figura evolucionista do selvagem não houve concepção mais obviamente implicada na opressão política e cultural do que a do nativo infantilizado. Além disso, que evidência poderia ser mais clara do distanciamento temporal do que situar o Agora do primitivo no Passado do adulto ocidental (FABIAN, 1983, p. 63). 
Muito embora a análise crítica de Fabian incida prioritariamente sobre a prática antropológica e suas narrativas etnográficas, a ideia de negação da coetaneidade se torna bastante produtiva para perspectivas críticas que se dedicam à compreensão das dinâmicas da colonialidade na instituição e reafirmação de identidades subalternizadas e de seus efeitos em situações pós-coloniais.

No campo de estudos genericamente identificados como decoloniais (ESCOBAR, 2003), a negação da coetaneidade tem se mostrado uma concepção útil para explicar uma das principais estratégias de instituição da diferença colonial, ou seja, "a classificação do planeta no imaginário colonial/moderno praticada pela colonialidade do poder, uma energia e um maquinário que transformam diferenças em valores" (MIGNOLO, 2000, p. 13). Ao hierarquizar diferenças, explica Mignolo (2010, p. 113), "[a] negação da coetaneidade, a invenção do primitivo e do subdesenvolvimento, ocultou o fato de que todos vivemos em um mesmo tempo cósmico e, ao mesmo tempo, em diferentes ritmos histórico-temporais".

Neste sentido, Mignolo, um dos principais teóricos decoloniais a ampliar o escopo da ideia de negação da coetaneidade para campos como a filosofia e a epistemologia, propõe que a negação estratégica da coetaneidade se dá como condição básica para a própria emergência do mundo moderno/colonial e a situa já nos primeiros momentos da chegada do europeu no que passou a se chamar América. Conforme o autor,

[a] expansão e colonização ocidentais, no século XVI, coincidiu com uma transformação radical do conceito de tempo que colidiu com o conceito de história e criou a condição necessária para situar diferentes enquadres conceptuais em algum lugar numa escala temporal que tinha seu ponto de chegada no presente da civilização cristã europeia do século XVI (MIGNOLO, 1998, p. 328).

As macronarrativas enunciadas desde as posições de poder tiveram como principal efeito o entrincheiramento de uma ideia de tempo linear da história universal com a própria ideia de missão civilizadora. Nestas condições, desde uma concepção eurocêntrica, "ser civilizado é ser moderno e ser moderno significa estar no presente. Assim, a negação da coetaneidade tornou-se uma das estratégias mais poderosas para a colonialidade do poder na subalternização de línguas, saberes e culturas" (MIGNOLO, 2000, p. 285). Para justificar a modernidade, foi necessário instituir seu momento pretérito, a pré-modernidade, que se materializava no atraso dos povos conquistados, de suas cosmovisões e epistemologias delas emergentes. Como sintetiza Mignolo, esta retórica se fundou em duas bases bastante nítidas, "[p]rimeiro, os primitivos estavam ligados à natureza e os povos civilizados 
estavam no auge da cultura. Segundo, os primitivos eram tradicionais e os europeus civilizados eram modernos" (MIGNOLO, 2011, p. 156).

Neste sentido, é possível reconhecer, desde o início da colonização, a emergência de uma ideia de indianidade primitiva, ligada à natureza e vinculada a um passado de tradições e costumes incompatíveis com a modernidade. Diferentes e cumulativas retóricas reforçaram, historicamente, esta construção discursiva, necessária para a manutenção da posição de subalternidade indígena e para justificar as violências que constituíram o mito irracional da modernidade (DUSSEL, 2000). Cristianização, civilização, assimilação, progresso e desenvolvimento foram, assim, alguns dos mais comuns índices do mito da modernidade.

Neste sentido, é importante reconhecer que, muito embora tenha sua origem já no início do confronto colonial, estas retóricas continuam circulando e seus efeitos continuam sendo bastante reais e, de muitas formas, estruturadores do colonialismo interno pós-independência política ${ }^{6}$. Como constatam Cadena e Starn (2010, p. 13), a "medição de sociedades nativas com réguas evolucionistas, ao ser implementada, produziu diferenças que, não obstante a imaginação ahistórica que as concebeu, deram formas às políticas coloniais que influenciaram nas relações póscoloniais". Assim, conforme os autores,

a oposição entre o 'primitivo' e o 'civilizado' [...] continuou sendo crucial no intrincado campo de significados, práticas e políticas de indianidade. [...] Consequentemente, gramáticas de contrastes análogas continuaram vinculando a indianidade com o atraso, a ruralidade e o analfabetismo, situando-a em oposição à modernidade, à urbanização e ao alfabetismo, as metas desejadas de desenvolvimento e progresso (CADENA; STARN, 2010, p. 16).

A partir deste enquadre teórico-analítico, não é difícil reconhecer no discurso da apresentadora Fabélia Oliveira os índices que retomam escalas sociolinguísticas mais amplas e antigas, entextualizando e atualizando discursos coloniais que reiteram uma representação generalizante, estática e essencializada de uma "indianidade autêntica", construída como inevitável e natural, mantida por rígidas fronteiras biológicas (ligadas à ideia de raça) e culturais (ligadas à ideia de etnicidade) (BUCHOLTZ; HALL, 2004, p. 374). São precisamente estes índices que enquadram sua visão sobre o que é ser índio no Brasil hoje. Ou melhor, para a apresentadora, esse "hoje indígena" sequer seria possível, pois segundo a lógica

6. Colonialismo interno, conforme Mignolo (2011, p. 135-136), pode ser compreendido como a continuidade dos efeitos de uma matriz colonial de poder que, mesmo após a descolonização de territórios, manteve as mesmas estruturas de controle e administração instituídas no período inicial de colonização europeia, nas quais a racialização hierárquica mantém-se como um dos pilares principais. Nestes contextos pós-independência, o poder passa ser exercido por elites locais que não se desvinculam, contudo, da experiência eurocêntrica. 
moderno/colonial reiterada em sua fala, a partir do momento em que usam "Rayban espelhado", "aparelho nos dentes", "comem de geladeira" (!), "usam tecnologia, tomam banbo de chuveiro e usam remédios químicos", deixam de ser "índios originais".

A ideia de "indianidade autêntica" que podemos perceber na fala da apresentadora parte do pressuposto de que qualquer forma de movimento físico, simbólico e/ou virtual, de contato, de trocas e apropriação intercultural por parte dos indígenas que a desestabilize torna suspeitas suas identidades étnicas e, como principal consequência, os tornariam "menos índios". Esta indianidade "de antigamente" deveria inclusive, segundo sua lógica, ser levada a cabo por comunidades e indivíduos indígenas, mesmo que para isso tenham "que morrer de malária de tétano... do parto...", já que isso "é a natureza".

A partir do exposto, a ideia de negação da coetaneidade indígena é aqui compreendida e implementada compreendendo todo o aparato discursivo que toma como enquadre referencial a existência indígena vinculada ao passado e, como consequência, que impõe suspeitas sobre as dinâmicas socioculturais, políticas e econômicas contemporâneas indígenas que desestabilizam esse enquadre ${ }^{7}$. Tratase, sem dúvidas, de uma apropriação interessada e posicionada da noção proposta por Fabian em interseção com a ampliação conceitual desenvolvida pelos estudos coloniais. Neste sentido, considero importante enfatizar que a expressão "negação da coetaneidade indígena", aqui empregada, não deve ser compreendida como se houvesse a possibilidade de uma coetaneidade intrínseca aos povos indígenas ou mesmo de que essa negação pudesse ser performada por povos ou indivíduos indígenas. Da forma como aqui articulada, entendo a negação da coetaneidade como profundamente vinculada a dinâmicas de poder que privilegiam certos lugares de enunciação que foram historicamente negados aos povos indígenas. Esses lugares de enunciação legitimam, por sua vez, certos discursos que assumem condição de autoridade, como o discurso acadêmico da Antropologia, na crítica de Fabian, ou discursos

7. Neste ponto específico da seção, agradeço a um/a dos/as pareceristas anônimos/as pelas observações extremamente críticas sobre minha apropriação da ideia de negação da coetaneidade de Fabian (1983). Os apontamentos apresentados, apesar de desfavoráveis à minha leitura do conceito, me permitiram elaborar um pouco mais minha abordagem, especialmente no que diz respeito ao risco de uma má compreensão da expressão "negação da coetaneidade indígena", que espero ter tornado menos ambígua para o/a leitor/a. Da mesma forma, espero ter tornado mais explícita minha compreensão da negação da coetaneidade como discurso performativo e, por se vincular a posições de poder, como estratégia deliberada em situações específicas. Naturalmente, assumo toda a responsabilidade pela leitura de Fabian (1983) e pelas articulações teóricas aqui realizadas desde sua proposta, aqui tomada como inspiração teórica para ampliação e indisciplinarização dos enquadres interpretativos dos estudos da linguagem (MOITA LOPES, 2006). 
da imprensa hegemônica, no caso de Fabélia, e dos discursos analisados na seção seguinte.

Além disso, o fato de a negação da coetaneidade ser aqui concebida e referida como uma estratégia retórica/discursiva parte de uma compreensão performativa da linguagem que possibilita a compreensão dessa negação como ação que não preexiste ao discurso, ou seja, ela se concretiza no próprio ato enunciativo. Como destaca Lander (2000, p. 15),

\begin{abstract}
com os cronistas espanhóis se inicia a 'massiva formação discursiva' de construção da Europa/ Ocidente e do outro, do europeu e do índio, desde a posição privilegiada do lugar de enunciação situado no poder. Esta construção tem como suposto básico o caráter universal da experiência europeia [...]. Ao construir-se a noção de universalidade a partir da experiência particular (provinciana) da história europeia e realizar-se a leitura da totalidade do tempo e do espaço da experiência humana a partir dessa particularidade, se institui uma universalidade radicalmente excludente.
\end{abstract}

Compreender a negação da coetaneidade como performativa não significa, contudo, que seus efeitos não sejam materiais e extrapolem o campo discursivo, afetando de muitas formas as vidas de quem tem essa coetaneidade negada, como a dor sentida pelo estudante xinguano por causa da fala da apresentadora Fabélia ou como a deslegitimação de demandas e direitos coletivos com base em especificidades culturais.

Ainda neste sentido, muito embora Fabian reconheça que a negação da coetaneidade como condição epistemológica só possa ser inferida a partir de seus efeitos e resultados (FABIAN, 1983, p. 34), o autor a compreende como aparato existencial, retórico e político e reconhece que "parece possível negar a coetaneidade de outra pessoa ou de outro grupo" (FABIAN, 1983, p. 34) o que, em minha intepretação, possibilita entendê-la como ação deliberada e estratégica em determinadas relações de poder assimétrico, como pretendo problematizar a partir de elementos discursivos da imprensa hegemônica brasileira, na seção seguinte.

\title{
3. "INDIANIDADE AUTÊNTICA" COMO ESTRATÉGIA NOS DISCURSOS DA IMPRENSA HEGEMÔNICA NO BRASIL
}

Torna-se, aqui, importante destacar também que, o que o discurso da apresentadora Fabélia não revela, ou o que é menos evidente em seu interesse por atualizar em sua performance uma ideia colonial de "indianidade autêntica" é o próprio caráter relacional, historicamente contingente e, acima de tudo, 
politicamente estratégico dessa indianidade forjada desde posições de poder ${ }^{8}$. Há interesses e ideologias em jogo neste enquadre discursivo muito difundidos em nossa sociedade. Como tenho enfatizado (cf. NASCIMENTO, 2017a), no Brasil, são exemplares discursos propagados pela mídia hegemônica que desqualificam comunidades e indivíduos indígenas que não se enquadram em prefigurações identitárias essencializadas de indianidade (PINTO, 2013), com os quais o discurso de Fabélia se alinha em perfeita harmonia. Tais discursos se afiliam, explicitamente, aos interesses políticos, econômicos e desenvolvimentistas, que, por sua vez, também retomam e implementam discursos e práticas coloniais, para os quais as terras indígenas são, historicamente, um empecilho para o progresso e para o desenvolvimento econômico nos moldes capitalistas.

Um exemplo notável da replicação destes discursos foi veiculado pela Revista VEJA, em 05 de maio de 2010, em reportagem intitulada "A farra da Antropologia oportunista", assinada por Leonardo Coutinho, Igor Paulin e Júlia de Medeiros. A reportagem especial, que causou grande repercussão à época de sua publicação, inclusive no meio acadêmico, se baseia predominantemente na deslegitimação identitária de grupos e indivíduos indígenas para defender a tese de que "uma indústria de demarcação" de terras indígenas e quilombolas estaria diminuindo potencialmente o território brasileiro que poderia ser utilizado para "a ampliação do agronegócio e do peso da nação no comércio mundial" (COUTINHO; PAULIN; MEDEIROS, 2010, p. 154).

É interessante perceber, neste sentido, que as principais situações criticadas e usadas como argumento pelos autores da reportagem dizem respeito exatamente às situações de movimento, de fluxos, hibridismos e mudanças socioculturais nas trajetórias indígenas, numa demonstração bastante explícita de como a ideia de "indianidade autêntica" é estratégica e regimentada por interesses não menos óbvios. Ao descrever situações de grupos indígenas específicos, os autores são enfáticos na desqualificação das vidas que não se enquadram na prefiguração da "indianidade original", como no caso de um homem autodeclarado indígena do povo Tupinambá, na Bahia. Segundo a reportagem, "seu cocar é de penas de galinha, como os que se usam no carnaval" e "sua 'tribo' é composta de uma maioria de negros e mulatos, mas

8. Naturalmente, reconheço o uso estratégico de uma identidade indígena essencializada também por povos e indivíduos indígenas. Neste caso, compreendo tal uso como necessário especialmente em arenas de embates interculturais, onde direitos indígenas são demandados e negociados. Compreendo, conforme Bucholtz e Hall (2004, p. 376), que este essencialismo por parte dos indígenas opere, contudo, a partir de interesses e ideologias divergentes dos aqui abordados, no sentido de buscar chamar a atenção para identidades e necessidades coletivas que seriam ignoradas. O essencialismo estratégico e situado, conforme as autoras, "propositadamente simplifica situações complexas para iniciar uma discussão que será posteriormente mais nuançada". 
também tem brancos de cabelos louros" (COUTINHO; PAULIN, MEDEIROS, 2010, p. 155). Ou ainda no caso da desqualificação de uma mulher indígena, líder de um grupo Guarani que reivindicava uma área no litoral sul de São Paulo, através da atribuição de descritores como "casada com um caminhoneiro (branco), tem carro, TV, computador, faz compra no supermercado e não conseguiu impedir a Funai de enterrar a melhor oportunidade de ascensão social que seus liderados tiveram" (COUTINHO; PAULIN; MEDEIROS, 2010, p. 160), referindo-se a um milionário e mal sucedido acordo então proposto pelo empresário Eike Batista, por sua vez, preso por ter sido acusado de corrupção e lavagem de dinheiro, em 2017.

Costumes e tradições "indígenas", ou a falta deles, são constantemente invocados na reportagem como sinal inequívoco de que a "indianidade autêntica" é a do passado e de que o que existe hoje são, conforme expressões usadas na reportagem, "os novos canibais", "macumbeiros de cocar" ou índios "made in Paraguai". Os autores da reportagem constatam que, "[e]m vários desses grupos, ninguém é capaz de apontar um ancestral indígena nem de citar costumes tribais" (COUTINHO; PAULIN; MEDEIROS, 2010, p. 159). E concluem com avaliação inequívoca, também com a mesma autoridade de Fabélia Oliveira sobre quem é índio original e quem não é: "[í]ndio que não é índio, negro que não é negro, reservas que abrangem quase $80 \%$ do território nacional e podem alcançar uma área ainda maior: o Brasil é mesmo um país único. Para espertinhos e espertalhões" (COUTINHO, PAULIN, MEDEIROS, 2010, p. 161).

Outro exemplo do uso estratégico de essencializações identitárias de povos e indivíduos indígenas teve como origem uma pesquisa encomendada ao Instituto de Pesquisas DataFolha pela Confederação da Agricultura e Pecuária do Brasil (CNA), em 2012, então presidida por Katia Abreu, conhecida ruralista e política brasileira. O objetivo da pesquisa era o de traçar um "perfil dos índios no Brasil", realizando, para isso, entrevistas com pessoas indígenas em diferentes regiões do país. As informações geradas a partir da referida pesquisa serviram como argumentos de verdade e autoridade em diferentes publicações que a ela se seguiram, especialmente as veiculadas pelo jornal A Folba de São Paulo, sendo algumas delas assinadas pela própria Kátia Abreu.

Numa de suas colunas semanais no jornal, intitulada "Uma antropologia imóvel", na seção Mercado, em 17 de novembro de 2012, a pecuarista e presidenta da CNA reconhece o caráter político da ciência antropológica e considera injustificável que

9. A interpretação feita pela CNA de alguns dados quantitativos gerados na pesquisa pode ser observada no material disponível em https://www.socioambiental.org/banco_imagens/pdfs/ Pesquisa_Datafolha_Perfil_indios_no_Brasil.pdf. Acesso em: 15 set. 2018. 
os conhecimentos sobre os povos indígena gerados pela Antropologia sejam usados "como instrumento de dominação e manipulação" (ABREU, 2012). A então senadora da república utiliza dados da pesquisa por ela encomendada ao Instituto DataFolha para confirmar sua interpretação de que "'povos da floresta" - pescadores, nômades e coletores - não são, há muitos anos, a cara e o coração predominante dos índios brasileiros dos nossos dias" e "que reduzir o índio à terra é o mesmo que continuar a querer e imaginá-lo nu" (ABREU, 2012). A presidenta do CNA, da mesma forma que a reportagem de VEJA, direciona suas críticas à Funai por "eternizar os índios como personagens simbólicos da vida simples e primitiva" (ABREU, 2012), mesmo que isso não corresponda mais às formas de vida contemporâneas desses indivíduos. E, da mesma forma que Fabélia Oliveira, utiliza índices linguísticos que apontam essa "indianidade legítima" ligada ao passado.

Na semana anterior a esta publicação, em 10 de novembro de 2012, o mesmo jornal já havia publicado uma matéria na seção Poder, com a manchete "Índios estão integrados ao modo de vida urbano, afirma pesquisa", já repercutindo os dados produzidos pela pesquisa paga pela CNA. Na reportagem, discursos que visam a comprovar que os "índios brasileiros" estão integrados à vida urbana, como em "segundo a pesquisa, 63\% dos índios têm televisão, 37\% têm aparelho de DVD e $51 \%$, geladeira, $66 \%$ usam o próprio fogão a gás e $36 \%$ já ligam do próprio celular" (FSP, Poder, 2012, p. 1), são alinhados com outros discursos que demonstram a dependência desses indivíduos de políticas públicas, como em " $64 \%$ dos índios são beneficiários do programa Bolsa Família, recebendo em média $\mathrm{R} \$ 153$ por mês" (FSP, Poder, 2012, p. 2). Aspectos de práticas comunicativas indígenas também são trazidas para o enquadre discursivo da reportagem, com informações de que, conforme a pesquisa, "a maioria dos índios (66\%) sabe ler, e 65\% sabem escrever na língua portuguesa" (FSP, Poder, 2012, p. 2).

Considerando a origem das informações e seu contexto de circulação, é notável o uso estratégico da dinamicidade cultural indígena na contemporaneidade para gerar suspeita sobre a legitimidade da identidade étnica e, mais precisamente, sobre direitos coletivos, como ao território. A aquisição de bens de consumo alegadamente urbanos, benefícios do governo e o uso da língua portuguesa em sua modalidade escrita são aqui importantes dimensões dessa integração. Briones (2010, p. 129), ao analisar afiliações identitárias de jovens mapuches em áreas urbanas da Argentina, reconhece que é precisamente sobre tais situações de fluxos e hibridismos culturais que recaem mais intensamente suspeitas sobre a autenticidade indígena. Conforme a autora, é diante dessas situações que "surgem maiores questionamentos e exigências mais estritas em relação à autenticidade, 
legitimidade e representatividade indígenas". Tais questionamentos, que se fundam na negação da coetaneidade indígena e na negação de toda a dinamicidade cultural vivenciada historicamente por povos e indivíduos reais, sejam eles indígenas ou não, são particularmente cruéis por, através de seus aparatos discursivos, como o usado por Fabélia Oliveira e os ilustrados nesta seção, manter a ideia de uma "indianidade original" externa à história e singularmente não moderna, situação para a qual, poucas alternativas restam para as pessoas indígenas que vivem a complexidade do tempo presente. Neste sentido, sintetizam Cadena e Starn,

[q]uem se veste com penas, pinta o rosto, usa trajes nativos ou, mais ainda, abraça publicamente suas tradições, corre o risco de se autoposicionar nos extremos semânticos do primitivismo exótico, o que Ramos (1998) denomina de 'índio hiper-real'. Por outro lado, quem parece não satisfazer as expectativas do estereótipo de 'penas e miçangas' será constantemente estigmatizado como 'mestiço', 'assimilado', ou, inclusive, impostor (CADENA; STARN, 2010, p. 17)

Não há, como se percebe, como fugir da perversidade das artimanhas da modernidade que, como visto, instituiu o tempo pretérito como o tempo ideal da "indianidade original". Se, por um lado, a retórica e as estratégias da modernidade foram particularmente eficazes em seus projetos globais de cristianização, civilização e desenvolvimento, através dos quais buscaram, à custa de toda forma de violência, assimilar as populações indígenas à "sociedade nacional", quando não exterminálas fisicamente; por outro, essas retóricas são constantemente acionadas ao revés para, na contemporaneidade, afirmar, desde interesses bem definidos, que índios originais eram aqueles do passado.

Este truque da modernidade/colonialidade envolve, certamente, as dimensões linguísticas. Não é sem propósito que a pesquisa do Instituto Datafolba e as publicações que dela se originaram, trazem o uso do português escrito como um dado relevante para a caracterização do "perfil" dos índios brasileiros. Neste sentido, a análise de Maher (2016) sobre a situação geral de povos indígenas no Brasil após a promulgação da Constituição de 1988 é particularmente relevante para a compreensão destas estratégias constantes de suspeição de identidades indígenas, especificamente, neste caso, com base nas dimensões das práticas comunicativas. Conforme a autora,

[a]té a promulgação da Constituição Brasileira de 1988, a ideologia linguística que operava era a de que os índios deveriam abandonar suas línguas e passar a utilizar apenas o português, de modo a permitir a sua total assimilação ao projeto de nação do país: é farta, na literatura especializada, evidências de modos de coerção ideológica, quando não física, utilizados para que os povos indígenas "abandonassem" suas línguas originárias [...]. A partir de então, no entanto, o quadro se reverteu: passou a ser legalmente permitido, e de certo modo encorajado o uso de suas línguas tradicionais. Mas observe-se que o que era uma permissão e incentivo, passou 
a ser entendido, também por muitos ativistas da causa indígena, como uma obrigatoriedade, principalmente entre muito daqueles engajados na implementação de projetos de educação bilíngue nas aldeias. Assim, também os discursos pró-indígenas se mostraram circunscritos pela ideologia linguística dominante: se antes, para serem brasileiros legítimos todos os povos indígenas tinham que falar português, agora, para serem considerados índios legítimos eles teriam que falar língua indígena (MAHER, 2016, p. 64).

Em síntese bastante crítica e elucidativa, conclui Maher, "no que tange aos povos indígenas a tendência é colocá-los como reféns do que seriam seus costumes ancestrais" (MAHER, 2016, p. 62). Neste ponto, utilizo a constatação da autora, juntamente com os discursos e as reflexões teóricas até aqui articulados para avançar uma hipótese de que, não apenas a Antropologia se fundou epistemologicamente na instituição do Outro preso ao passado, como critica Fabian, ou que se trata apenas de uma replicação discursiva interessada por parte da mídia hegemônica brasileira. Desde meu lugar de fala, avento a hipótese (auto)crítica de que também os estudos da linguagem, especialmente em suas vertentes dedicadas à compreensão de línguas e realidades sociolinguísticas indígenas a partir de bases epistemológicas modernas, reproduzem a negação da coetaneidade indígena ao utilizar como aparato teórico-analítico concepções fixas, estabilizantes e homogeneizadoras que reiteram, ou mesmo geram, uma ideia de autenticidade de identidades indígenas (NASCIMENTO, 2017a; 2017b). Considerando esta hipótese, a seção seguinte apresenta brevemente o relato de uma pesquisa de caráter metateórico por mim coordenada, visando a uma compreensão situada das abordagens de línguas e povos indígenas na produção acadêmica no campo dos estudos da linguagem no Brasil.

\section{A NEGAÇÃO DA COETANEIDADE NA PRODUÇÃO ACADÊMICA BRASILEIRA SOBRE LÍNGUAS E SITUAÇÕES SOCIOLINGUÍSTICAS DE POVOS INDÍGENAS}

O estudo que gerou as informações aqui sinteticamente relatadas compôs o projeto de pesquisa mais amplo "Alternativas situadas para descolonização de práticas, ideologias e regimes de linguagem em contextos pós-coloniais interculturais" (2013/2018) e foi desenvolvido como plano de trabalho de Iniciação Científica (2017/2018) por mim orientado, sob o título "Um olhar crítico sobre globalização e contemporaneidade indígena nos estudos da linguagem ${ }^{\prime \prime 10}$.

10. O plano de trabalho foi desenvolvido em parceria com o estudante de graduação em Letras José Pedro Morais de Araújo e, para o acesso ao relatório da pesquisa, remeto o leitor a Araújo e Nascimento (2018). Somos gratos ao CNPq pela concessão ao estudante da bolsa de Iniciação Científica (PIBIC) que viabilizou sua participação na pesquisa. 
Para o desenvolvimento da pesquisa, partimos de uma primeira hipótese de que são duas as áreas mais produtivas no campo dos estudos da linguagem que se dedicam às línguas e situações sociolinguísticas indígenas, a saber, i) a que se dedica à descrição de características sistêmico-funcionais, sob diferentes enfoques teóricos, de partes de língua, em suas dimensões fonético-fonológicas, morfossintáticas e, em alguns casos, textuais e discursivas; e ii) a que se dedica à compreensão das diferentes realidades sociolinguísticas das comunidades indígenas, desdobrando-se em áreas como da educação escolar bilíngue e dos direitos linguísticos, buscando, basicamente, compreender os fatores socioculturais internos e externos que interferem na vitalidade das línguas indígenas. Não assumimos as áreas como isoladas uma da outra, mas como áreas com perfis teórico-analíticos e metodológicos delimitáveis e distinguíveis.

Uma segunda hipótese assumida para o estudo foi a de que, muito embora com objetivos distintos, as duas áreas compartilham, de forma geral, de pressupostos epistemológicos modernos fundados como parte de processos e estratégias coloniais/nacionalistas para governabilidade de corpos e territórios conquistados. O primeiro desses pressupostos compartilhados diz respeito à própria categoria "língua", inventada como entidade estável, discreta, delimitável, nomeável, enumerável e mapeável (IRVINE; GAL, 2000; MAKONI ; MEINHOF, 2006; MAKONI; PENNYCOOK, 2007). Deste primeiro pressuposto, segue-se um segundo, que se refere à fundamentação dessas áreas na ideologia do monolinguismo, aqui compreendida, em síntese, como um complexo de ideias, crenças e práticas que assumem como fundamento "que as pessoas são intrinsecamente monolíngues, suas línguas são padrões (puros) e seus territórios limitados e sociolinguisticamente homogêneos" (BLOMMAERT, 2006, p. 518). Neste sentido, mesmo estudos que se dedicam à compreensão de situações de contatos linguísticos, de bilinguismos e que impactam campos como dos direitos linguísticos, da educação em língua materna etc., operariam desde a noção reificada e monolíngue de "língua", tendo como principal desdobramento teórico a noção de bi- ou multilinguismo como uma "pluralização do monolinguismo" (MAKONI, PENNYCOOK, 2007, p. 22). O terceiro pressuposto, profundamente vinculado aos dois anteriores, é de que as referidas áreas compartilham, ainda, a assunção inequívoca e estabilizante da tríade herderiana que liga língua, cultura e território. Esta ligação que, por sua vez, remonta ao Romantismo alemão dos séculos XVIII e XIX, serviu como modelo ideológico para a imaginação dos Estados-nação, mas também para regimentar ideias de tradição e identidade perpassadas por ideologias de linguagem (BAUMAN; BRIGGS, 2003; BLOMMAERT, 2010). No mundo pós-colonial, a tríade é particularmente útil 
para a compreensão do modelo de identidade étnica que parece ser privilegiado nos estudos de linguagem que se dedicam aos povos indígenas. Como explicam Bucholtz e Hall,

[a] tradição erudita do Romantismo, motivada pela emergência do nacionalismo, ligou indelevelmente língua à etnicidade de forma quase biológica [...]. Nesta versão de etnicidade, que resiste tanto no discurso acadêmico como no popular, a identidade está enraizada não em formas genéticas, mas formas culturais herdadas, especialmente a língua, que simboliza e, em modos essencialistas mais extremos, corporifica iconicamente a identidade cultural distintiva de um grupo étnico. A compreensão romântica da língua ligou-a à essência espiritual de seus falantes: consequentemente as línguas, assim como as identidades culturais que deram existência a elas, foram pensadas para serem necessariamente separadas e não sobrepostas. De modo inverso, a similaridade cultural percebida ou assumida produziu uma expectativa de similaridade linguística (e vice-versa) (BUCHOLTZ; HALL, 2004, p. 374)

A terceira e última hipótese assumida na pesquisa foi a de que, considerando os pressupostos anteriores, pouca atenção tem sido dada pelas áreas mencionadas às dimensões, aos fenômenos e às práticas socioculturais e sociolinguísticas indígenas que, de alguma forma, desestabilizam os fundamentos sintetizados nos pressupostos. É precisamente na interseção entre a reprodução desses pressupostos epistemológicos hegemônicos e a pouca atenção dispensada à mobilidade (física, geográfica, virtual, simbólica etc.) que, inegavelmente constituem também as experiências indígenas na contemporaneidade, que identificamos uma dimensão da negação da coetaneidade que, assumimos como hipótese geral, constitui o perfil da maior parte da produção acadêmica sobre povos, grupos e indivíduos indígenas no Brasil nos estudos da linguagem.

Tendo em vista estas hipóteses, tomamos como campo de pesquisa para sua averiguação a Biblioteca Digital Curt Nimuendajún ${ }^{\prime \prime}$. A Biblioteca foi escolhida como campo de pesquisa por ser considerada um dos maiores repositórios da produção acadêmica nacional e internacional concernentes às populações indígenas e por disponibilizar na íntegra essa produção. Metodologicamente, a pesquisa se deu em duas fases, sendo a primeira dedicada a uma etnografia virtual (HINE, 2000), perspectiva a partir da qual a Bliblioteca foi concebida como uma comunidade de prática; e a segunda dedicada às buscas no acervo digital a partir de termos que indiciassem, desde nossas perspectivas, dimensões da contemporaneidade indígena. Estas etapas foram desenvolvidas no primeiro semestre de 2018.

Muito embora reconheçamos a Biblioteca como um repositório de produções de diversos pesquisadores e pesquisadoras, pudemos perceber, já no início da

11. A Biblioteca Digital encontra-se hospedada em: $<$ http://www.etnolinguistica.org $>$. Acesso em: 15 set. 2018. 
etnografia virtual, indícios de um posicionamento epistemológico através de elementos que reforçam a intrínseca e alegada relação entre língua, cultura, território e identidade étnica, quando observamos o slogan que caracteriza o repositório, logo abaixo de seu nome, na página inicial: "linguas e culturas indígenas sul-americanas". Não há, contudo, qualquer apresentação na Biblioteca do que se compreende por "língua", por "cultura" ou por "indígena". Compreendemos, assim, no decorrer da pesquisa etnográfica, que a não explicitude dessas categorias, especialmente sobre o que incluem ou excluem, poderia ser interpretada como um enquadre metateórico, ou mesmo metadiscursivo, que se completa ou se ampara no perfil dos trabalhos que o compõe. Um outro indício que reforçou esta interpretação foi a aba "tags", constituída, basicamente, por etnônimos indígenas que servem como ligações aos trabalhos referentes aos povos e línguas por eles codificados ${ }^{12}$, compreendidas também como índices que agrupam os trabalhos com base em identidades etnolinguísticas, de alguma forma, estabilizantes. Naturalmente, essas interpretações são hipotéticas e compreendemos que os elementos destacados, por si só, não dizem nada isoladamente. Nossas interpretações foram geradas considerando toda a trajetória da pesquisa.

Para a segunda etapa da pesquisa, ou seja, a das buscas nas produções que constituem o acervo digital da Biblioteca, foram estabelecidos critérios de filtragem condizentes com o enquadre teórico mais amplo da pesquisa. Dentre esses critérios, destaco aqui i) o temporal, uma vez que buscamos produções posteriores ao ano de 2010, quando surgem publicações importantes que intersecionam linguagem e globalização e que poderiam servir de referência aos trabalhos depositados na Biblioteca (ex. BLOMMAERT, 2010; COUPLAND, 2010) e ii) a abordagem de povos, grupos ou indivíduos indígenas no Brasil, mesmo que publicados em outras línguas, como espanhol, inglês ou francês, uma vez que a Biblioteca congrega trabalhos produzidos no exterior.

Para a escolha das palavras de busca, partimos de algumas articulações teóricas que nos pareceram importantes. A primeira delas foi assumir que fenômenos contemporâneos, como a globalização e suas consequências, também afetam grupos e indivíduos situados às margens do sistema mundo moderno/colonial, como já apontado por Wang et al. (2014) e argumentado por Nascimento (2017a; 2017b). A segunda articulação, relacionada à primeira, reconheceu no vocabulário teórico corrente nos estudos críticos da linguagem na atualidade formas de conceber e compreender dimensões comunicativas em contextos contemporâneos de mobilidade, fluxos e hibridismos humanos e semióticos (BLOMMAERT, 2010;

12. Outras tags são elaboradas a partir de termos analíticos, como "fonologia", "futuro nominal" etc. 
CANAGARAJAH，2013; JACQUEMET，2005，2016; GARCÍA; WEI，2014; PENNYCOOK, 2012). Nesta direção, buscamos produções correspondentes a termos como globalização, mobilidade, multimodalidade, práticas transidiomáticas, translinguagem, superdiversidade, translíngue, beteroglóssico, crossing, polilinguismo, metrolinguismo, codemeshing, linguajamento, bibridismo, plurilinguismo, plurilíngue, multilinguismo, multilíngue e bilinguismo. Estes termos também foram buscados nas outras línguas mencionadas como critério de filtragem. Os pouquíssimos trabalhos arrolados a partir desses termos foram acessados e, a partir do mecanismo de busca interna nos arquivos, geralmente em formato pdf (portable document format), os contextos de uso dos termos foram identificados, de forma a possibilitar a compreensão dos sentidos a eles atribuídos e se, de alguma forma, eram compatíveis com nossas próprias perspectivas teóricoanalíticas. Em alguns casos de aparente compatibilidade teórica, os trabalhos foram lidos na íntegra.

Não é meu objetivo aqui fazer uma descrição detalhada dos resultados encontrados, por razões de espaço, mas também pelo escopo deste trabalho, que tem como fio condutor a ideia de negação da coetaneidade indígena. Assim, destaco apenas algumas dimensões das interpretações mais gerais que a pesquisa possibilitou, que me parecem mais significativas para meu argumento. A primeira delas diz respeito ao termo "globalização" que, por mais amplo e generalizante que seja, nos remeteu a apenas um trabalho. Tratava-se, contudo, de uma matéria da revista Isto É, de 11 de março de 2009, sob o título "Acredite: Um terço das línguas está sumindo", assinada por Cláudia Jordão ${ }^{13}$. Muito embora não se configure como uma produção acadêmica, a matéria foi analisada para a pesquisa por ter sido o único resultado da busca pelo termo. De forma geral, a ideia assumida de globalização, como o título já indica, é prioritariamente distópica e vê como consequência direta o desaparecimento de línguas minorizadas ao redor do mundo. Nenhum tipo de agência de povos e indivíduos indígenas nestes processos é destacado, como, por exemplo, as diferentes formas de apropriação de infraestruturas de globalização, como as tecnologias de comunicação e informação, talvez a face mais visível da globalização geocultural e mais acessível aos povos indígenas, como já demonstram alguns trabalhos como, por exemplo, Delgado e Jesus (2018); Jesus (2014); Maher (2016); Moita Lopes (2018); Nascimento (2018).

Os resultados mais significativos gerados pela busca com o termo "mobilidade", por sua vez, nos remeteram a trabalhos que tratam de migrações indígenas que, muito embora seja uma dimensão importante das experiências indígenas e demonstre que

13. Matéria disponível em: < https://istoe.com.br/8170_ACREDITE+UM+TERCO+DAS+LING

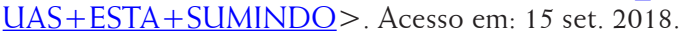


a mobilidade física é fenômeno antigo entre essas populações, nenhuma interseção com linguagem foi desenvolvida nos trabalhos encontrados. Esses trabalhos sobre migrações indígenas, além disso, não se enquadram disciplinarmente no campo dos estudos da linguagem (i.e. Linguística, Linguística Aplicada etc.).

Para a maioria dos outros termos não encontramos qualquer resultado e, quando eram encontrados, não constatamos qualquer compatibilidade teórica com nossa própria pesquisa. Termos mais comuns e de uso mais recorrente nas áreas aqui abordadas, como "multilinguismo" e "bilinguismo" apresentaram alguns resultados, contudo, as perspectivas adotadas partiam dos pressupostos modernos apresentados anteriormente, especialmente de concepções essencializadas e estáveis de língua e de "pluralilzação do monolinguismo", não desvinculadas de suas contrapartes culturais e territoriais, ou seja, de uma identidade étnica não menos fixa.

$\mathrm{O}$ resultado positivo mais significativo, me parece, refere-se a uma dissertação de mestrado localizada pelo termo "plurilíngue". Trata-se do trabalho de Mutua Mehinaku (2010), indígena xinguano, intitulado "Tetsualï: pluralismo de linguas e pessoas no Alto Xingu". Este trabalho se torna bastante significativo neste contexto por apresentar, desde um posicionamento geopolítico não hegemônico, a categoria indígena "tetsualii" para a compreensão de fluxos e hibridismos culturais e linguísticos que não são vistos, necessariamente, como negativos ou prejudiciais para uma "identidade indígena". Conforme definição do autor,

[a] palavra kuikuro tetsualü pode ser traduzida como 'misturado', como uma mistura de cores no colorido de alguma coisa, uma mistura de comidas diferentes, uma mistura de tamanhos diferentes. [...] Tetsualü é também uma mistura de línguas e dialetos na fala, uma mistura de etnias na história de vida de uma pessoa. Este trabalho gira em torno da idéia de tetsualü quando se fala de pessoas e de línguas. O Alto Xingu é tetsualü, a aldeia de Ipatse é tetsualü eu sou tetsualü (MEHINAKU, 2010, p. 01)

O trabalho de Mehinaku é ainda interessante por abordar dimensões contemporâneas das experiências comunicativas indígenas, incluindo a apropriação de tecnologias de comunicação, vista por ele como algo positivo por permitir aos jovens indígenas a interação com não indígenas e outros povos indígenas em escalas translocais, através, por exemplo, do que chama de "aki humini (enviador de palavras), 'e-mails', correio eletrônico" (MEHINAKU, 2010, p. 182); e também por apresentar uma visão não distópica ou essencialista de práticas comunicativas híbridas ligadas a esses novos meios de comunicação online, incluindo exemplos de misturas de recursos linguísticos das línguas indígenas com o português.

De toda forma, o trabalho de Mehinaku parece ser ainda mais importante por demonstrar que, se a maior parte dos trabalhos identificados na pesquisa não 
abordam formas contemporâneas das experiências indígenas, essas não passaram despercebidas na análise de um acadêmico indígena, muito provavelmente por serem vivenciadas desde outras experiências geo- e corpo-políticas, ou seja, por uma outra visão de mundo. Esta interpretação, certamente, poderia ser ampliada para dimensões da geopolítica do conhecimento, que de muitas maneiras reproduz os efeitos da negação da contemporaneidade indígena, o que, entretanto, fugiria ao escopo deste trabalho.

\section{CONSIDERAÇÕES FINAIS}

A principal interpretação, ainda que não definitiva, possibilitada pela pesquisa relatada na seção anterior é a de que, me parece, existe uma "identidade indígena" pressuposta e privilegiada na produção acadêmica analisada. Muito embora abordada de forma panorâmica, essa produção parece pressupor uma identidade que se funda, basicamente, em concepções de língua, cultura e território (que, normalmente, são subsumidas na noção não menos naturalizada de "comunidade", cf. PRATT, 1987) diretamente vinculadas e dependentes uma das outras para a manutenção da "indianidade", por sua vez, critério necessário para a criação do objeto da descrição de línguas e de situações sociolinguísticas "indígenas".

Em outras palavras, o conjunto de estudos observados parece privilegiar como objeto de estudos uma identidade indígena monolíngue (mesmo quando as pessoas ou os grupos são bi- ou plurilíngues), culturalmente homogênea (mesmo que os fluxos e intercâmbios sejam mais antigos que a própria colonização e tenham sido irremediavelmente complexificados pelos processos recentes de globalização) e constituída por uma comunidade territorial e culturalmente bem delimitada e não menos estável e homogênea. Como sumariza Blommaert,

[o] que vemos aqui é como as funções da linguagem são territorializadas, presas a ambientes locais particulares aparentemente construídos como estáticos. A língua aparentemente funciona bem em seu lugar próprio, original, e perde funcionalidade tão logo as ligações estáveis, originais, 'autóctones' (ou 'nativas', 'aborígenes') entre língua e lugar são quebradas. Consequentemente, programas que visam ao estímulo e promoção dessas línguas locais (invariavelmente, línguas maternas de pessoas aparentemente monolíngues e monoculturais inerentemente) prendem os falantes dessas línguas a um lugar e reforça a conexão fixa presumida entre povo e ambiente - um claro reflexo da sincronia saussureana. Tudo isso soa mais ou menos aceitável, ao menos enquanto alguns aspectos da realidade são convenientemente omitidos. Um aspecto bastante perturbador da realidade contemporânea, como sabemos, é a mobilidade. Nas estruturas sociais contemporâneas, as pessoas se movem, tanto no espaço geográfico real, como no espaço social, simbólico. E todos esses processos de mobilidade parecem desempenhar conexões complexas com a linguagem, incluindo atitudes e planejamento linguístico (BLOMMAERT, 2010, p. 45). 
Neste sentido, me parece plausível pensar que, também para as áreas de estudos da linguagem, das quais as abordadas na seção anterior são apenas alguns exemplos, a negação da coetaneidade indígena, mantenedora de uma identidade preferível como objeto de estudo, é estratégia e condição necessárias para a própria existência do campo. Naturalmente, não se trata de uma crítica à Biblioteca ou, principalmente, aos trabalhos individuais que a compõem, mas de uma (auto)crítica às próprias bases epistemológicas moderno/coloniais da Linguística como grande área que, ironicamente, muito tem avançado na compreensão de identidades como processos situados e contingenciais performados na/através da linguagem, mas que não se percebe como constituída por discursos que, também performativamente, continuam forjando identidades fixas e, o que me parece mais grave, no caso de povos e indivíduos indígenas, ainda presas a um passado que já não corresponde às experiências contemporâneas reais que alega descrever. Pelo menos não da forma totalizante e generalizada como os estudos analisados parecem mostrar. Neste sentido, pouco se afastariam, num nível mais profundo e radical, dos discursos da imprensa hegemônica brasileira, incluindo o violento discurso da apresentadora Fabélia Oliveira.

Não se trata, obviamente, de negar a indianidade "da tribo, dos ritos, dos chás, das ervas, das curas e dos mistérios", pois, como nos informa Jaider Esbell, ela também existe. Mas de ampliar os enquadres interpretativos de modo que essa indianidade possa ser compreendia, primeiro, não como presa ao passado, mas compartilhando uma contemporaneidade diferente e alternativa à imaginada pela modernidade eurocentrada; e, depois, não excluindo de seu escopo o que é gerado pela mobilidade, pelos fluxos, pelo contato, como por exemplo as situações de grupos e indivíduos que não falam "línguas indígenas" ou que, necessariamente, translinguajam (MIGNOLO, 2003), de modo a existirem nas experiências de vida às margens, ou grupos e pessoas indígenas desaldeados ou urbanizados, ou ainda indivíduos indígenas que se afiliam a identidades múltiplas, e mesmo contraditórias, afinal, como constata Rajagopalan (2003, p. 63), mesmo não se referindo direta ou exclusivamente aos povos e indivíduos indígenas, "[o] bom selvagem nunca saiu do mundo imaginário do seu criador Jean-Jacques Rousseau, para pisar na terra dos mortais comuns. Pelo que se vê, as chances de se deparar com ele em nosso mundo pós-moderno globalizado são cada vez mais remotas".

\section{REFERÊNCIAS}

ABREU. K. (2012). Uma antropologia imóvel. Folba de São Paulo. Mercado, 17 de novembro. Disponível em: https://www1.folha.uol.com.br/fsp/mercado/78428-uma-

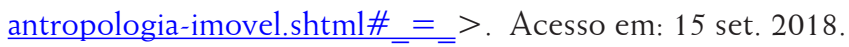


ARAÚJO, J. P. M.; NASCIMENTO, A. M. (2018). Um olhar crítico sobre globalização e contemporaneidade indígena nos estudos da linguagem. Relatório Final do Programa Institucional de Bolsas Iniciação Científica (PIBIC). Universidade Federal de Goiás. Goiânia. 2018. Inédito.

BASTOS, L. C.; LOPES, L. P. M. (2011). (orgs.). Estudos de identidade: entre saberes e práticas. Rio de Janeiro: Garamond.

BAUMAN, R.; BRIGGS, C. (2003). Voices of modernity: language ideologies and the politics of inequality. Cambridge: Cambridge University Press.

BLOMMAERT, J. (2005). Discourse: a critical introduction. Cambridge: Cambridge University Press.

BLOMMAERT, J. (2006). Language Ideology. In: ENCYCLOPEDIA of Language and Linguistics. [S.1.]: Elsevier, v. 6. p. 510-522.

BLOMMAERT, J. (2010). The sociolinguistics of globalization. Cambridge: Cambridge University Press.

BRIONES, C. (2010). "Nuestra lucha recién comienza": experiencias de pertenencia y de formaciones mapuches de yo. In: CADENA, M.; STARN, O. (2010). Introducción. In: CADENA, M.; STARN, O. (eds.). Indigeneidades contemporáneas: cultura, política y globalización. Lima: IEP/IFEA. p.115-137.

BUCHOLTZ, M.; HALL, K. (2004). Language and identity. In: DURANTI, A. (Ed.). A companion to linguistic antbropology. Malden, MA, USA: Blackwell Publishing. p. 369-394.

CADENA, M.; STARN, O. (2010). Introducción. In: CADENA, M.; STARN, O. (eds.). Indigeneidades contemporáneas: cultura, política y globalización. Lima: IEP/IFEA. p. 9-42.

CANAGARAJAH, S. (2013) Translingual Practice: Global Englishes and Cosmopolitan Relations. New York: Routledge.

COUPLAND, N. (2010). (ed). The Handbook of Language and Globalization. Oxford: Blackwell.

COUTINHO, L.; PAULIN, I.; MEDEIROS, J. (2010). A farra da Antropologia oportunista. Revista VEJA. Ano 43, n. 18, 05 de maio. p. 154-161.

DELGADO, P. S.; JESUS, N. T. (2018). Povos Indígenas no Brasil: Perspectiva no fortalecimento de lutas e combate ao preconceito por meio do audiovisual. Curitiba, PR: Brazil Publishing. 
DUSSEL, E. (2000). Europa, modernidad y eurocentrismo. In: LANDER, E. (comp.). La colonialidad del saber: eurocentrismo e ciencias sociales - Perspectivas latino americanas. Buenos Aires: CLACSO. p. 39-51.

ESCOBAR, A. (2003). "Mundos y conocimientos de otro modo": El programa de investigación de modernidad/colonialidad latinoamericano. Tabula Rasa, n. 1, enero/ diciembre. p. 51-86.

FABIAN, Johannes. (1983). Time and the Other: bow Antbropology makes its object. New York: Columbia University Press.

FOLHA DE SÃO PAULO. (2012). Índios estão integrados ao modo de vida urbano, afirma pesquisa. Poder, 10 de novembro. Disponível em: < https://www1.folha.uol. com.br/fsp/poder/77168-indios-estao-integrados-ao-modo-de-vida-urbano-afirmapesquisa.shtml $>$ Acesso em: 15 set. 2018.

GARCÍA, O.; WEI, L. (2014). Translanguaging: Language, Bilingualism and Education. New York: Palgrave Macmillan.

HINE, C. M. (2000). Virtual Ethnograpby. London/Thousand Oaks/New Delhi: Sage Publications.

IRVINE, J.; GAL, S. (2000). Language ideology and linguistic differentiation. In: KROSKRITY, P. V. (ed.). Regimes of language: Ideologies, Politics and Identities. Santa Fe, NM: School of American Research Press. p. 35-85.

JACQUEMET, M. (2005). Transidiomatic practices: language and power in the age of globalization. Language and communication, n. 25. p. 257-277.

JACQUEMET, M. (2016). Language in the Age of Globalization. In: BONVILLAIN, N. (ed.). The Routledge Handbook of Linguistic Antbropology. New York: Routledge. p. 329347.

JESUS, N. T. et al. (2014). Presença indígena no Facebook e a construção de narrativas. Fronteiras e Debates, vol.1, n. 2. p. 9-28.

LANDER, E. (2000). Ciencias sociales: saberes coloniales e eurocéntricos. In: LANDER, E. (comp.). La colonialidad del saber: eurocentrismo e ciencias sociales - Perspectivas latino-americanas. Buenos Aires: CLACSO. p. 9-38. 
MAHER, T. M. (2010). Políticas linguísticas e políticas de identidade: currículo e representações de professores indígenas na Amazônia ocidental brasileira. Currículo sem Fronteiras, v.10, n.1, pp.33-48.

MAHER, T. M. (2016). Sendo índio na cidade : mobilidade, repertório linguístico e tecnologias. Revista da Anpoll, n. 40. p. 58-59.

MAKONI, S.; MEINHOF, U. (2006). Linguística aplicada na África: desconstruindo a noção de "língua". Tradução de Luiz Paulo da Moita Lopes. In: MOITA LOPES, L. P. (org.). Por uma linguística aplicada indisciplinar. São Paulo: Parábola. p. 191-213.

MAKONI, S.; PENNYCOOK, A. (2007). Disinventing and reconstituting languages. In: MAKONI, S.; PENNYCOOK, A. (eds.). Disinventing and reconstituting languages. Clevedon/Buffalo/Toronto: Multilingual Matters. p. 1-41.

MEHINAKU, M. (2010). TETSUALÜ: pluralismo de linguas e pessoas no Alto Xingu. Dissertação (Mestrado em Antropologia Social) - Programa de Pós-graduação em Antropologia Social/Museu Nacional. Rio de Janeiro: Iniversidade Federal do Rio de Janeiro.

MIGNOLO, W. D. (2000). Local/histories/Global designs: coloniality, subaltern knowledges, and border thinking. Princeton: Princeton University Press.

MIGNOLO, W. D. (2010). Desobediencia epistémica: retórica de la modernidad, lógica de la colonialidad y gramática de la descolonialidad. Buenos Aires: Ediciones del signo.

MIGNOLO, W. D. (2011). The darker side of Western Modernity: global futures, decolonial options. Durham/London: Duke University Press.

MOITA-LOPES, L. P. (2006). Por uma Linguística Aplicada Indisciplinar. São Paulo : Parábola.

MOITA-LOPES, L. P ; BASTOS, L. C. (2010). (orgs.). Para além da identidade: fluxos, movimentos e trânsitos. Belo Horizonte : Editora UFMG.

MOITA-LOPES, L. P. (2018). Guarani/Portuguese/Castelliano - Rap on the borderland : transidiomaticity, indexicalities and text spectacularity. In : CAVALCANTI, M. C. ; MAHER, T. M. (eds.) Multilingual Brazil : language resources, identities and ideologies in a globalized world. London/New York : Routledge.

NASCIMENTO, A. N. (2017a). Plurilinguismos indígenas no mundo globalizado. Organon, v.32, n. 62, p. 1-19. Disponível em: < https://seer.ufrgs.br/organon/article/ view/70481/42118> Acesso em: 15 set. 2018. 
NASCIMENTO, A. M. (2017b). Globalization in the margins: toward elements for a sociolinguistics of mobility from Indigenous experiences. Signótica, vol. 29, n. 2, p. 269-301.

NASCIMENTO, A. M. (2018). Counter-hegemonic linguistic ideologies and practices in Brazilian Indigenous rap. In: ROSS, A. S.; RIVERS, D. J. (eds.). The sociolinguistics of Hip-Hop as critical conscience: dissatisfaction and dissent. New York: Palgrave Macmillan. p. 213-235.

PENNYCOOK, A. (2012). Language and mobility: unexpected places. Bistol/Buffalo/Toronto: Multilingual Matters.

PINTO, J. P. (2013). Prefiguração identitária e hierarquias linguísticas na invenção do português. In: MOITA LOPES, Luiz Paulo (org.). O português no século XXI: cenário geopolítico e sociolinguístico. São Paulo: Parábola. p. 120 - 143

PRATT, M. L. (1987). Linguistic Utopias. In: FABB, N. et al. (eds.). The linguistics of writing: arguments between language and literature. New York: Nethuen Inc. p. 48-66.

QUIJANO, A. (1992). Colonialidad y modernidad-racionalidad. In: BONILLA, H. (comp.). Los conquistados: 1492 y la población indígena de las Américas. Bogotá: Tercer Mundo/Flacso. p. 437-447.

QUIJANO, A. (2000) Colonialidad del poder, eurocentrismo y América Latina. In: LANDER, E. (comp.). La colonialidad del saber: eurocentrismo y ciencias sociales. Perspectivas latinoamericanas. Buenos Aires: CLACSO. p. 193-238.

RAJAGOPALAN, K. (2003). Por uma linguística crítica: linguagem, identidade e questão ética. São Paulo: Parábola.

SILVA, D. (2017). Investigating violence in language: an introduction. In: Silva, D. (ed.). Language and Violence: pragmatic perspectives. Amsterdan/Philadelphia: John Benjamins. p. 1-29.

WANG, X. et al. (2014). Globalization in the margins: toward a reevalution of language and mobility. Applied Linguistics Review, vol.5, n.1. p. 23-44.

Recebido: $1 / 10 / 2018$

Aceito: 15/10/2018 